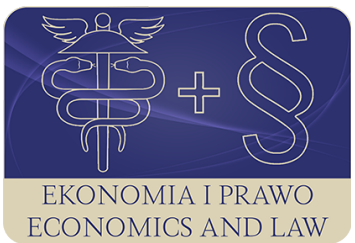

EKONOMIA I PRAWO. ECONOMICS AND LAW

Volume 20, Issue 3, September 2021

p-ISSN 1898-2255, e-ISSN 2392-1625

www.economicsandlaw.pl

EKONOMIA I PRAWO
ECONOMICS AND LAW

ORIGINAL ARTICLE

received 12.07.2020; revised 10.09.2021; accepted 30.09.2021

Citation: Życzkowska, E., \& Dziuba, J. (2021). Revenues from agricultural tax in the context of the principle of financial independence of municipalities. Ekonomia i Prawo. Economics and Law, 20(3), 709-725. https://doi.org/10.12775/EiP.2021.042.

\title{
Revenues from agricultural tax in the context of the principle of financial independence of municipalities
}

\section{ELŻBIETA ŻYCZKOWSKA}

corresponding author

Wrocław University of Economics and Business, Faculty of Economics and Finance, Department of Finance and Accounting, ul. Nowowiejska 3, 58-500 Jelenia Góra, Poland

$\square$ elzbieta.zyczkowska@ue.wroc.pl

(D) orcid.org/0000-0001-8263-9964

\section{JAROSEAW DZIUBA}

Wrocław University of Economics and Business, Faculty of Economics and Finance, Department of Finance and Accounting, Poland

$\square$ jaroslaw.dziuba@ue.wroc.pl

(D) orcid.org/0000-0002-3167-8995

\begin{abstract}
Motivation: The presented study addresses the important and current problem of agricultural tax and the resulting revenues in the context of financial independence of local government units. The scope of financial independence held by a municipality is significantly influenced by the right to exercise limited fiscal power. It means that the state provides municipalities with a number of powers to shape the local tax system, to set tax rates, to introduce individual tax exemptions, allowances and amortizations.

Aim: The main purpose of the article is to present the importance of agricultural tax as the source of generating own revenues by municipalities in Poland, in the years 20152019 , in the context of the principle of financial independence of municipalities. The supplementary purpose is to analyse and assess exercising the rights in terms of shaping revenues from agricultural tax in municipalities.

Results: The analysis covers the level and share of revenues from agricultural tax in total revenues and municipal own revenues as well as the amount of revenues lost on its account. The conducted research has shown that agricultural tax plays the greatest role as
\end{abstract}


the source of own revenues in managing the budgets of rural municipalities. However, it can be noticed that the fiscal function of the tax under study is increasingly smaller in each municipal category. It should be indicated that the structure of agricultural tax, which is basically unrelated to profitability and the volume of production in agriculture, in turn, translates into a low level of own revenues potential in municipalities. The system of taxing agriculture with agricultural tax, from the perspective of financial independence of municipalities, remains ineffective and the degree of independence presented by municipalities in this respect is far from a satisfactory level. The conducted analysis addressing correlations resulting from various types of reductions in agricultural tax against revenues from this tax showed that the scale of reductions, as the effect of using various tools by municipalities, was minimal and did not exceed $1 \%$ (which makes approx. $0.5 \%$ ). The exception is the possibility of reducing the upper tax rates by a municipality.

Keywords: financial independence; own revenues; agricultural tax; fiscal power JEL: H25; H29; H39; H72

\section{Introduction}

The delegation of public tasks, including the right to use own property, to the local level results from the process of decentralization carried out by public administration. In effect of such decentralization, the local government units (LGUs) acquire the right to perform the assigned tasks. Therefore, the consequence of decentralization is the financial independence of a municipality being the basic local government unit. Independence also means the right of a local government to obtain funds independently (as the income aspect of financial independence). The scope of financial independence of a municipality is significantly influenced by the right to exercise limited fiscal power. A municipality gained the right to set the tax level within the limits defined by the legislator and collect it to its own budget, which significantly increases the level of its own revenues (Pytlak, 2017, pp. 108, 116). The agricultural tax is one of the local taxes which contributes in full to the budget, i.e. represents the source of revenue at the lowest local government level, such as a municipality, also including cities with county rights, and in their case the municipal authority remains the respective tax authority (municipal head, mayor or city president). The agricultural tax structural components and the way of shaping them by these authorities determine the possibilities for conducting municipal own tax policy (using the existing instruments of fiscal power).

The article is divided into a theoretical part, covering the source literature overview, which discusses financial independence of municipalities and the construction of agricultural tax in Poland, and also an empirical part, which presents the level of total revenues, municipal own revenues and those collected from agricultural tax. The degree of financial independence of local government units will be assessed using the indicator for revenues from agricultural tax in relation to own revenues and total revenues. In addition, the analysis addresses reductions in revenues from agricultural tax in terms of lowering the upper tax rates, 
tax reliefs and exemptions or write-offs on tax arrears. The summary of the article presents the conclusions from the conducted research.

\section{The concept of financial independence: literature overview}

Independence, according to PWN Polish Language Dictionary (Stownik Języka Polskiego PWN, 2021), is defined as the possibility to decide about oneself, independently from someone else, from someone's influence. In turn, according to the Dictionary of Contemporary Polish Language, independence should be approached as an individual, separate entity, functioning on its own terms or the possibility of coping without anyone's help (Dunaj, 1996, p. 998). From the perspective of independence referring to any institution, it can be said that an institution is independent when it is not influenced or pressured by anyone, is capable of deciding about itself and is not subject to anyone's control (Bańko, 2000 , p. 546). Therefore, in order for an institution to pursue its goal and specific tasks, it should be able to organize and involve the respective resources (cf. Gawłowski, 2013, pp. 204-205). In the case of the local government units' independence, this concept is considered in many aspects and on many levels. Independence of a local government unit is defined as - the constitutionally guaranteed, separate and defined by law sphere of the activities carried out by local government units. It is a tool which enables them to make their own decisions without prior interference of the state authorities. However, they are subject to some verification by the supervisory authorities. It results from the fact that these units represent the entities of decentralized administration. Therefore, the independence of self-government units is the basic feature of self-government as the goal and effect of decentralization, and also as the power to make independent decisions. The competences of local authorities in the scope of influencing the type and level of revenues remain one of the most important manifestations and, at the same time, the conditions of local government financial independence, hence the principle of fiscal power has received the rank of constitutional and international standard. The Constitution of the Republic of Poland (1997) in Art. 168 states that "... units of local government have the right to set the level of taxes and local fees within the scope specified in the Act", whereas Art. 9, section 3 of the European Charter of Local Self-Government (1985) introduces the principle following which "... at least part of the financial resources of local communities should come from local fees and taxes, the level of which these communities are entitled to determine, to the extent specified by the Act". The source literature emphasizes the multifaceted nature of this principle and highlights its various aspects (including political, property and financial aspects). Thus, the independence of local government units can be analysed in terms of the following aspects (Zawora, 2010, pp. 137-138):

- legal - this independence results from the legal order according to which a local government unit holds legal personality. It provides independence and the ability to decide about one's own affairs; 
- political - associated with the right to choose a specific course of action, consistent with the idea of an organization or with the political idea of a specific party. It is directly related to the implementation of the affairs specific for a given local community;

- organizational - involves granting the right to create own bodies, to establish own organizational units and to appoint the respective positions;

- economic - is associated with the implementation of tasks and conducting economic activities by a given local government unit;

- financial - it is the right to decide on the structure and amount of revenues, as well as the type and level of expenditure.

As it has already been mentioned, the independence of local government units, in particular the financial one, can be analysed on many levels. It is connected, e.g., with the right for self-determination of the financial plan (budget) taking the responsibility for its implementation and the possibility of influencing the structure of own revenues. Moreover, local government units are free to decide on the type and amount of public funds spending in a given local government unit (see Surówka, 2013, p. 147). In general terms, the financial independence of local government units can be approached as granting local authorities the right to decide on the amount and structure of income, expenditure, revenues and outlays as well as develop and execute the budget of a given unit. However, the financial independence of local government units should not be understood as their full autonomy in terms of managing the obtained funds. Therefore, it is neither absolute nor implicit. ${ }^{1}$ The legal doctrine distinguishes the concept of financial independence from the financial autonomy of local government units. Full financial autonomy is understood as creating one's own rules of functioning in the economic and financial sphere, regardless of the central authorities (Bogucka-Felczak, 2019, pp. 186-187).

The source literature provides two basic methods used in defining the scope of financial independence in relation to local government units. In a broader sense, the discussed units have a legally guaranteed possibility to decide independently about the allocation of all funds held in their possession (originating from the budget and from their own revenues). In a narrower sense, however, it applies to these funds alone which can be obtained by the local government units on their own (more in: Kornberger-Sokołowska, 2001, p. 50).

Due to the multifaceted nature of financial independence, the assessment of its degree is quite difficult. The source literature distinguishes several measures that can help to illustrate, in a synthetic way, the level of independence of a local government unit. The following measures referring to the financial independence of local government units are used most frequently:

1 The limits of this independence are determined, e.g., by the provisions of the Constitution and the Acts which provide that in terms of financial management, local government units are allowed to act in accordance with the binding legal provisions alone (more in: Bury, 2005, p. 33; Franczak, 2013, p. 159; Glumińska-Pawlic, 2003, p. 47). 
- revenues and expenditure of local government units in relation to revenues and expenditure of the state budget;

- revenues and expenditure in relation to public revenues and expenditure;

- revenues and expenditure of local government units in relation to GDP;

- own revenues compared to total revenues;

- tax revenues compared to total revenues;

- investment expenditure in relation to total revenues.

The above set of indicators shows that in order to determine financial independence, the indicators whose structure is focused on budget revenues are used more often. The first three indicators define the financial independence of a given local government unit in relation to the entire public finance sector, whereas the remaining indicators specify information about the financial independence of the analysed local government unit (Jaworska \& Kożuch, 2012, p. 133). An important issue in determining the scope of financial independence of a local government unit is identifying its revenue sources as well as its competences which allow shaping them.

\section{Methods}

The research methods used in the study consist in analysing the collected materials and formulating conclusions on their basis. To this end, both qualitative and quantitative methods were applied. First, the source literature and the respective legal acts in terms of financial independence and agricultural tax were reviewed. Quantitative methods are based on the statistical data analysis in the following categories: total revenues of municipalities, own revenues of municipalities, municipal revenues from agricultural tax, lost revenues from agricultural tax. The degree of financial independence of local government units will be assessed using the indicator for revenues from agricultural tax in relation to own revenues and total revenues. In addition, the analysis addresses the reductions in revenues from agricultural tax in terms of lowering the upper tax rates, tax reliefs and write-offs on tax arrears. The time range covers the years 2015-2019. The aforementioned municipal revenues (including cities with county rights), urban-rural municipalities and rural municipalities were covered by the analysis.

\section{General principles of the agricultural tax construction in Poland}

The agricultural tax is one of the local taxes which contributes in full to the budget, i.e. remains the source of revenue at the lowest local government level, such as municipalities, also including cities with county rights and in their case the municipal authority remains the respective tax authority (municipal head, mayor or city president). The agricultural tax structural components and the way 
of shaping them by these authorities determine the possibilities for conducting municipal own tax policy (using the existing instruments of fiscal power). The scope of municipal power to impose taxes with regard to agricultural tax is very limited. The municipal council does not have the power to set (reduce) the tax rate in a direct way. However, the municipal power to tax is manifested by the right to lower the average rye purchase price adopted for the tax calculation, which means that the council has an indirect influence on the tax rate. In addition, the municipal council has little influence on another structural component of the tax, i.e. tax base, through the possibility of including some villages in the tax district other than the one specified for the municipality in the relevant regulation by the Minister of Finance. The council may also apply to the voivodship parliament for including the entire municipality in another tax district, which affects the tax base level. The municipal council competences also include the application of tax write-offs and exemptions other than those specified in the Act. The resources of utilised agricultural area expressed in comparative fiscal hectares are the subject of taxation with agricultural tax. These resources include land classified in the land and building register as utilised agricultural area or as wooded and bushland on the utilised agricultural area, except for the land used for the purposes of conducting economic activity other than agricultural activity.

Pursuant to Art. 4 (1) of the Agricultural tax act (1984), the tax base is:

- for agricultural land - comparative fiscal hectares determined based on the area, types and classes of utilised agricultural area resulting from the land and building register as well as the inclusion in the tax district ${ }^{2}$;

- for other land - hectares resulting from the land and building register. The agricultural tax for the fiscal year is:

- monetary equivalent of $2.5 \mathrm{q}$ of rye per one comparative fiscal hectare of agricultural land,

- monetary equivalent of $5 \mathrm{q}$ of rye per one hectare of the remaining land.

Since $2014^{3}$, the basis for determining the agricultural tax is the average rye purchase price 4 for the period of 11 quarters before the quarter preceding the fiscal year.

Pursuant to Art. 12 the exemptions apply, i.a., to: utilised agricultural area classified as class V, VI and VIz as well as wooded and bushland established on utilised agricultural area, land located along the border road, arable land,

2 There are 4 tax districts, including municipalities and cities, depending on economic, production and climatic conditions. This classification is performed by the Minister of Finance in consultation with the Minister of Agriculture, after consulting the National Council of Agricultural Chambers (Regulation of the Minister of Finance, 2001).

3 Until 2014, the basis for determining the agricultural tax was the average rye purchase price for the first three quarters of the year preceding the fiscal year.

4 The price is determined based on the announcement by the President of the Statistics Poland, published in the Official Gazette of the Republic of Poland "Monitor Polski”, by 20 October of the year preceding the fiscal year. 
meadows and pastures covered by melioration, land intended for establishing a new agricultural holding or expansion of the already existing one up to an area not exceeding 100 ha, land of agricultural holdings resulting from the management of wastelands (for a period of 5 years), land of agricultural holdings obtained through exchange or consolidation (for a period of 1 year), land of agricultural holdings where agricultural production was stopped, provided that the exemption may apply to no more than $20 \%$ of the utilised agricultural area of an agricultural holding, but not more than $10 \mathrm{ha}$ - for a period not longer than 3 years, in relation to the same land. In addition, the structure of the agricultural tax also includes reliefs (Article 13 of the Act) which cover, e.g., investment relief, relief in natural disaster situations and mountain relief ${ }^{5}$. The mountain relief applies to areas located in the mountain and submontane areas ${ }^{6}$. Pursuant to the Act, it covers the locations where at least $50 \%$ of the utilised agricultural area is located at $350 \mathrm{~m}$ above sea level. The list of these locations in a particular voivodship is established by the voivodship parliament.

Taxpayers of agricultural tax represent natural persons, legal persons, organizational units, companies without legal personality that own land, autonomous land owners, perpetual lessees of land or the owners of land constituting the ownership of the State Treasury or local government units (Agricultural tax act, 1984 , Art. 1 and Art. 3). The legislator provides for reliefs and exemptions in agricultural tax (Agricultural tax act, 1984, Chapter IV). Some reliefs and exemptions are calculated ex officio, and some - at the taxpayer's request (Table 1). In the case of tax exemptions, the ones in terms of an objective criterion have also been identified. In this case, the exemption takes place only after meeting the conditions specified by law. The following entities are exempt: universities, public and non-public organizational units covered by the education system and their bodies, scientific institutes and auxiliary scientific units of the Polish Academy of Sciences, sheltered employment or professional activity establishments, research institutes, entrepreneurs holding the status of a research and development centre, National Property Stock.

\section{Fiscal power in terms of shaping revenues from agricultural tax by the local government units: results}

Article 168 of the Constitution of the Republic of Poland (1997) provides local government units with a certain scope of fiscal power, thus giving the possibility to influence the amount of collected budget revenues. Local taxes and fees re-

${ }^{5}$ It should be noted here that the reliefs in natural disaster situations as well as the reliefs and exemptions introduced by the resolution of the municipal council (other than those specified in the Act, but taking into account the provisions on the state aid) will constitute de minimis aid in agriculture.

6 The agricultural tax on land located in submontane and mountain areas is reduced by $30 \%$ for the land classified as class I, II, IIIa, III and IIIb, and by $60 \%$ for the land classified as class IVa, IV and IVb. 
main the main source of tax revenues for local budgets. They are introduced by law in a uniform manner throughout the country, however, are provided to the local government as a source of revenues and thus the local authorities have obtained certain fiscal powers from the legislator (Marczak \& Piotrowska-Marczak, 2017, p. 453). It means that the state, by providing municipalities with a number of powers aimed at shaping the local tax system, the powers to set tax rates, to introduce individual tax exemptions, reliefs and write-offs, unburdens itself of dealing with them on an annual basis (Etel, 2010, p. 380). At the same time, it also defines precisely the method for collecting revenues from specific sources, thus setting the top-down income-based independence limits of local government units, which can be shifted through an appropriate "incentive system" used by municipalities (Ślebocka, 2013, p. 292). The degree of state influence on shaping revenues from local taxes may vary. The central regulation of local taxes can take the following forms (Chadata, 2002, pp. 242-243):

- determining the scope of permissible forms of local taxes, from which the individual local government bodies can choose and apply taxes within their territory, which they consider the most convenient and efficient;

- establishing the generally binding system of local taxes along with the simultaneous possibility of allowing optional taxes, supplementing the obligatory ones;

- defining the uniform structure of individual local taxes, while leaving it to the local government bodies to decide on the tax rates;

- determining the allowable maximum, possibly also minimum tax rate, which means that within the limits set by the maximum and minimum burden level, the local tax rates may be set in a relatively unrestrained manner by the relevant local government bodies;

- specifying uniform, obligatory local tax rates for all local authorities, possibly diversified in accordance with the criteria adopted by the state;

- allowing local government bodies to apply exemptions and reliefs in local taxes which scope and rates, determining the basic level of tax burden, are set by the state, uniformly throughout the entire country.

In Poland, fiscal power is exercised only by the municipalities that obtain their own tax revenues. In turn, the active implementation of fiscal power may result in the reduction of tax revenues and, on the other hand, may ensure accomplishing other goals, justified from the perspective of municipal development (more in: Brzozowska \& Kogut-Jaworska, 2016, pp. 328-329) - cf. Table 2. Agricultural tax is a minor source of revenue in the budget structure of local government units. A larger share of revenues from agricultural tax is presented in rural municipalities, and definitely smaller in urban ones, including cities with county rights (Table 3 ).

The data in Table 3 show that the share of revenues from agricultural tax in total revenues and own revenues collected by municipalities presents a declining tendency. This applies to all types of municipalities in the analysed period. In the case of municipalities (including cities with county rights), the share 
of agricultural tax revenues in total revenues ranges from $0.06 \%$ in 2015 to $0.04 \%$ in 2019 . Regarding the share of revenues from agricultural tax in own revenues of these municipalities, a downward trend was also observed, i.e. from $0.09 \%$ to $0.06 \%$ in 2019 . In urban and rural municipalities the discussed share ranges from $1.82 \%$ to $1.14 \%$ (refers to the share in total revenues), whereas the share in own revenues - $3.56 \%$ to $2.58 \%$ in 2019 . Even in the municipalities of rural profile alone, a declining tendency was recorded each consecutive year. The share of revenues from agricultural tax in total revenues ranged from $2.60 \%$ in 2015 to $1.63 \%$ in 2019 , while in relation to own revenues from $6.01 \%$ down to $4.32 \%$, respectively. In the same period, a decrease in revenues from agricultural tax was observed. The discussed revenues dropped, on average, by a few percent against the previous year (Chart 1). The biggest change was recorded in municipalities in 2016/2015 - the decrease by $10.48 \%$. If the year $2019 / 2015$ is compared, it can be noticed that the revenues from agricultural tax went down by over $10 \%$ in urban municipalities, by $1.46 \%$ in urban and rural municipalities and by $4.31 \%$ in rural municipalities. Even though, in some years, a slight increase in these revenues was recorded - e.g., in urban-rural municipalities, in 2019/2018 the increase amounted to $5.25 \%$.

In the area of local taxes and fees and in this case - in relation to agricultural tax, municipal councils were authorized, by means of resolutions, to introduce tax exemptions other than those provided for in the Act. Granting a tax relief may consist in: spreading tax payment into a larger number of instalments, deferring tax payment date or cancelling all tax liabilities. Reliefs and exemptions constitute an internal tax structure. They aim at reducing the tax amount by lowering the tax base, tax rates or the tax amount itself (Etel et al., 2006, p. 35). Such action is generally focused on enhancing due behaviour in the target group (e.g. as in the case of investment allowance). The application of reliefs and exemptions in agricultural tax results more often from the occurrence of a certain situation beyond the taxpayer's control. An example is the relief in the event of a natural disaster - in practice, agricultural producers do not have the possibility to take advantage of such a relief, because a natural disaster has to be announced by the competent authorities, and if it is not, the head of the municipality/mayor/city president cannot apply such relief.

The application of reliefs and exemptions by the municipality results in the reduction of revenues from agricultural tax and thus has financial consequences in the form of lost revenues. Therefore, local government units are reluctant to make decisions about the reduction of agricultural tax level (Table 4). As mentioned earlier, municipalities are not eager to make decisions on lowering the agricultural tax revenues. In all municipalities, in almost all areas of reductions in agricultural tax, the ratio of these items to the sum of agricultural tax revenues ranges from $0.1 \%$ up to $0.8 \%$. The exception refers to the reduction of the upper tax rates. This indicator remains the highest in the case of rural municipalities. The revenues lost by these municipalities due to the reduction of the upper tax rates amounted to 20.6\% in 2015 (municipalities lost over 
PLN 206 million). In the subsequent years, the respective level ranged from $9 \%$ to $10 \%$ in these municipalities. In the case of urban-rural municipalities, the lost revenues presented the level of 6-7\%, with the exception of 2015, when the level of $15 \%$ was recorded. The lowest loss of revenues on this account was reported in urban municipalities - 4.5\% on average, in 2015 it reached $6.9 \%$ and in $2019-1.7 \%$. It can be observed that in each category of municipalities the largest amount of lost revenues was recorded in 2015.

The conducted analysis of correlations resulting from various types of reductions in agricultural tax against revenues from this tax shows that the scale of reductions connected with using the tools by municipalities was minimal and did not exceed $1 \%$ (i.e. approx. $0.5 \%$ ). The exception is the possibility of municipalities to reduce the upper tax rates.

\section{Conclusions}

Agricultural tax is one of many local taxes, the revenues of which contribute entirely to the municipal budget. In this respect municipalities have limited fiscal power which, in turn, allows implementing the principle of financial independence of municipalities in the context of municipal revenues. Although the revenues from agricultural tax represent revenues of a given local government alone, its regulation is performed at a central level, which takes various forms, thus imposing certain restrictions in terms of fiscal power held by a municipality (which means that municipalities have specific powers of taxation based on which they can influence fiscal charges without, however, the authority to establish them). In this respect the following aspects can be listed, e.g., establishing a uniform tax structure while allowing the local authorities to decide about the tax rates level; determining the allowable maximum and possibly also minimum tax rate, which means that within the limits set by the maximum and minimum level of fiscal charges, the tax rates may be defined relatively independently by the relevant local government bodies; establishing uniform, obligatory tax rates for all local authorities, possibly differentiated according to the criteria adopted by the state; allowing local government bodies to apply exemptions and reliefs in agricultural tax, the scope and rates of which determining the basic level of the tax burden are set by the state, uniformly throughout the entire country (more in: Chadała, 2002, pp. 242-243).

The application of selected tools based on the competences assigned to municipalities results in the reduction of municipal own revenues. Hence the conclusion that municipalities are not particularly interested in granting the broadly understood reductions in terms of agricultural tax (even though such activities perform a tax stimulation function).

The conducted analysis shows that the local government units used their powers to a limited extent, only in the case of adopting tax rates lower than the upper limits, which obviously resulted in the reduction of revenues from this source. In all types of municipalities, practically in every area of the applied 
reductions, a downward trend can be observed, which from the perspective of write-offs on tax arrears has a positive dimension.

To sum up, it can be indicated that the agricultural tax is a relatively inefficient source of own revenues collected by municipalities. From the standpoint of the financial independence level presented by municipalities, its ineffectiveness is related to its structure. The purchase price of rye, i.e. the only one agricultural product, is adopted as the tax base. In addition, it should be noted that its importance in agricultural production in Poland is decreasing year by year. According to the Statistics Poland (2020b), in 2018 the share of rye sown in total crops was at the level of only $8 \%$.

\section{References}

Bańko, M. (Ed). (2000). Inny stownik języka polskiego PWN. PWN.

Bogucka-Felczak, M. (2019). Zasada samodzielności finansowej jednostek samorządu terytorialnego i jej realizacja w przepisach prawa i orzecznictwie Trybunału Konstytucyjnego. Przedsiębiorczość i Zarządzanie, 20(3), 181-193.

Brzozowska, K., \& Kogut-Jaworska, M. (2016). Władztwo podatkowe w ocenie samodzielności dochodowej gmin w Polsce. Annales Universitatis Mariae Curie-Sktodowska: Sectio H, Oeconomia, 50(1), 327-337. https://doi. org/10.17951/h.2016.50.1.327.

Bury, A. (2005). Dochody wtasne i ich znaczenie dla dochodów i wydatków budżetów samorządowych. Wyższa Szkoła Finansów i Informatyki w Łodzi.

Chadała, P. (2002). Samodzielność finansowa jednostek samorządu terytorialnego. Annales Universitatis Mariae Curie-Sktodowska: Sectio H. Oeconomia, 36, 227-245.

Dunaj, B. (1996). Stownik wspótczesnego języka polskiego. Wilga.

Etel, L. (2010). Granice władztwa podatkowego jednostek samorządu terytorialnego w świetle art. 168 Konstytucji. In P.J. Lewkowicz, \& J. Stankiewicz (Eds.). Konstytucyjne uwarunkowania tworzenia i stosowania prawa finansowego i podatkowego (pp. 379-388). Temida2.

Etel, L., Dowgier, R., Lewkowicz, P.J., Liszewski, G, Popławski, M. \& Tyniecki, M. (2006). Prawo podatkowe w pytaniach i odpowiedziach. Lexis Nexis.

Europejska Karta Samorządu Terytorialnego, sporządzona w Strasburgu dnia 15 października 1985 r. [European Charter of Local Self-Government of October 15, 1985] (Dz.U. $1994 \mathrm{nr} 124$ poz. 607) (Poland).

Franczak, A. (2013). Prawne gwarancje samodzielności finansowej samorządu terytorialnego a zasada adekwatności dochodów do przydzielonych zadań oczekiwana strukturą i wysokością subwencji ogólnej. Zeszyty Naukowe Instytutu Administracji Akademii im. Jana Dtugosza w Częstochowie: Gubernaculum et Administratio, 1(7), 157-171. 
Gawłowski, R. (2013). Samodzielność jednostek samorządu terytorialnego w kontekście realizacji polityk publicznych. In D. Plecka (Ed.). Wspótczesne wyzwania administracji rządowej i samorządowej (pp. 203-218). Adam Marszałek.

Glumińska-Pawlic, J. (2003). Samodzielność finansowa jednostek samorząu terytorialnego $w$ Polsce: studium finansowoprawne. Uniwersytet Śląski w Katowicach.

Jaworska, M., \& Kożuch, A.J. (2012). Ocena przydatności wybranych metod WAP w analizie samodzielności finansowej gmin. Metody Ilościowe w Badaniach Ekonomicznych, 13(1), 131-137.

Konstytucja Rzeczypospolitej Polskiej z dnia 2 kwietnia 1997 r. [The Constitution of the Republic of Poland of April 2, 1997] (Dz.U. 1997 nr 78 poz. 483) (Poland).

Kornberger-Sokołowska, E. (2001). Decentralizacja finansów publicznych a samodzielność finansowa jednostek samorządu terytorialnego. PWN.

Marczak, J., \& Piotrowska-Marczak, K. (2017). Daniny publicznoprawne a samodzielność finansowa gmin polskich i hiszpańskich: studium porównawcze. Studia i Materiaty Wydziału Zarządzania i Administracji Wyższej Szkoty Pedagogicznej im. Jana Kochanowskiego w Kielcach, 21(3), 449-460.

Ministry of Finance. (2015-2019a). Annual reports on the implementation of municipal budgets in the years 2015-2019. Retrieved 25.11.2020 from https:// mf-arch2.mf.gov.pl/web/bip/ministerstwo-finansow/dzialalnosc/ finanse-publiczne/budzety-jednostek-samorzadu-terytorialnego / sprawozdania-budzetowe.

Ministry of Finance. (2015-2019b). Annual reports on the implementation of municipal budgets in the years 2015-2019. Retrieved 25.11.2020 from https:// www.gov.pl/web/finanse/sprawozdania-budzetowe.

Pytlak, M. (2017). Samodzielność finansowa gmin w Polsce: podstawy prawne i ograniczenia. Gospodarka i Finanse, 8, 105-118.

Rozporządzenie Ministra Finansów z dnia 10 grudnia 2001 r. w sprawie zaliczenia gmin oraz miast do jednego z czterech okręgów podatkowych [Regulation of the Minister of Finance of 10 December 2001 on including municipalities and cities in one of the four tax districts] (Dz.U. $2001 \mathrm{nr} 143$ poz. 1614) (Poland).

Słownik Języka Polskiego PWN. (2021). Samodzielność. Retrieved 29.10.2020 from http://sjp.pwn.pl/szukaj/samodzielność.html.

Statistics Poland. (2020a). Local data bank. Retrieved 24.11.2020 from https:// bdl.stat.gov.pl/BDL/start.

Statistics Poland. (2020b). Statistical yearbook of agriculture 2019. Retrieved 01.02.2020 from https://stat.gov.pl/en/topics/statistical-yearbooks/statistical-yearbooks/statistical-yearbook-of-agriculture-2019,6,14.html.

Surówka, K. (2013). Samodzielność finansowa samorządu terytorialnego w Polsce: teoria i praktyka. PWE. 
Ślebocka, M. (2013). Dochody własne a problematyka samodzielności dochodowej jednostek samorządu terytorialnego na przykładzie gmin województwa tódzkiego. Ekonomiczne Problemy Ustug, 108, 291-301.

Ustawa z dnia 15 listopada $1984 \mathrm{r}$. o podatku rolnym [Agricultural tax act of November 15, 1984] (Dz.U. 1984 nr 52 poz. 268) (Poland).

Zawora, J. (2010). Samodzielność finansowa samorządów gminnych Podkarpacia. Zeszyty Naukowe SGGW w Warszawie: Ekonomika i Organizacja Gospodarki Żywnościowej, 81, 137-145.

\section{Acknowledgements}

Author contributions: authors have given an approval to the final version of the article. Authors contributed to this work equally.

Funding: this research was fully funded by the Wroclaw University of Economics and Business.

Note: the results of this study were presented at the 8th International Conference Sustainable Finance \& Accounting: Economy, Ethics, Environment (April 19-21, 2021, Torun, Poland). 


\section{Appendix}

\section{Table 1.}

\section{Types of reliefs and exemptions in agricultural tax in general terms}

\begin{tabular}{|c|c|c|}
\hline Type & & Specification \\
\hline \multirow[t]{2}{*}{ Reliefs } & ex officio & relief for sub-mountain and mountain areas \\
\hline & $\begin{array}{l}\text { upon request } \\
\text { of the taxpayer }\end{array}$ & investment relief, relief resulting from the state of natural disaster \\
\hline \multirow{15}{*}{ 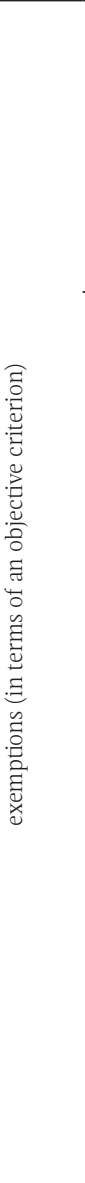 } & ex officio & $\begin{array}{l}\text { - utilised agricultural land class V, VI and VIz as well as wooded land and bushland } \\
\text { established on agricultural land; } \\
\text { - land located along the border road; } \\
\text { - ecological land; } \\
\text { - land covered by water reservoirs used to supply population with water; } \\
\text { - land under levees and inter-levee land; } \\
\text { - land entered in the register of monuments, provided it is developed and maintained } \\
\text { in accordance with the provisions on the protection and care of monuments. }\end{array}$ \\
\hline & $\begin{array}{l}\text { upon request } \\
\text { of the taxpayer }\end{array}$ & $\begin{array}{l}\text { - arable land, grassland and pastures subject to drainage - in the year in which } \\
\text { the crops were damaged as a result of drainage works; }\end{array}$ \\
\hline & & $\begin{array}{l}\text { - land intended for the establishment of a new agricultural holding or expansion } \\
\text { of the existing one to an area not exceeding } 100 \text { ha; }\end{array}$ \\
\hline & & $\begin{array}{l}\text { - land subject to the ownership right or the right of perpetual usufruct, acquired under } \\
\text { a sales agreement; }\end{array}$ \\
\hline & & - land being the subject of perpetual usufruct agreement, \\
\hline & & $\begin{array}{l}\text { - land included in the Agricultural Property Stock of the State Treasury, subject to per- } \\
\text { manent development; }\end{array}$ \\
\hline & & $\begin{array}{l}\text { - agricultural land created from the development of wastelands - for a period of } 5 \\
\text { years from the year following the finalisation of development; }\end{array}$ \\
\hline & & $\begin{array}{l}\text { - land of agricultural holdings obtained through the exchange or consolidation - for } 1 \\
\text { year following the year in which the land was replaced or consolidated; }\end{array}$ \\
\hline & & $\begin{array}{l}\text { - land of agricultural holdings where agricultural production was stopped, however, } \\
\text { the exemption may not apply to more than } 20 \% \text { of the agricultural area of an agri- } \\
\text { cultural holding, but not more than } 10 \text { ha - for the period not longer than } 3 \text { years, } \\
\text { in relation to the same land; }\end{array}$ \\
\hline & & $\begin{array}{l}\text { - land constituting homestead plots of the members of agricultural production coop- } \\
\text { eratives who: }\end{array}$ \\
\hline & & - reached retirement age, \\
\hline & & - are disabled and included in the disability group I or II, \\
\hline & & - are disabled with a severe or moderate degree of disability, \\
\hline & & $\begin{array}{l}\text { - are completely incapable of working on a farm or incapable of independent ex- } \\
\text { istence; }\end{array}$ \\
\hline & & $\begin{array}{l}\text { - land located within the area of the family allotment garden, except for those owned by } \\
\text { entities other than allotment gardeners or garden associations. }\end{array}$ \\
\hline
\end{tabular}

Source: Own preparation based on Agricultural tax act (1984). 
Table 2.

Revenues of municipalities* in the years 2015-2019 (in thousands PLN)

\begin{tabular}{llrrr}
\hline Years & Types of municipalities & Total revenues & Own revenues & Agricultural tax revenues \\
\hline \multirow{2}{2}{015} & urban municipalities & 90091003,49 & 56702719,63 & 50323,32 \\
& urban-rural municipalities & 29628892,10 & 15192091,59 & 540372,54 \\
& rural municipalities & 38507443,42 & 16452231,73 & 1002277,14 \\
\hline \multirow{2}{2}{016} & urban municipalities & 97096221,05 & 58383276,16 & 45049,07 \\
& urban-rural municipalities & 34669046,08 & 15835075,44 & 514378,53 \\
& rural municipalities & 44449694,11 & 16785452,08 & 954030,57 \\
\hline \multirow{2}{2017}{ urban municipalities } & 103022763,70 & 61543564,18 & 44168,78 \\
& urban-rural municipalities & 38046255,73 & 16965614,57 & 505825,99 \\
& rural municipalities & 48649805,20 & 17879681,06 & 935190,83 \\
\hline \multirow{2}{2018}{ urban municipalities } & 112415850,07 & 66847593,67 & 44573,54 \\
& urban-rural municipalities & 41505423,46 & 18452785,14 & 505933,14 \\
& rural municipalities & 53012114,24 & 19641207,61 & 931548,22 \\
\hline \multirow{2}{2019}{} & urban municipalities & 123712725,80 & 70683708,61 & 45018,18 \\
& urban-rural municipalities & 46549312,70 & 20667939,74 & 532513,25 \\
& rural municipalities & 58793857,06 & 22193256,68 & 959066,91 \\
\hline
\end{tabular}

Notes:

* urban municipalities also cover cities with county rights.

Source: Own preparation based on Statistics Poland (2020a).

Table 3.

Revenues from agricultural tax in the structure of municipal revenues in 2015-2019 (in \%)

\begin{tabular}{llcc}
\hline Years & Types of municipalities & $\begin{array}{c}\text { Share of revenues from agricultural } \\
\text { tax in total revenues }\end{array}$ & $\begin{array}{c}\text { Share of revenues from agricultural } \\
\text { tax in own revenues }\end{array}$ \\
\hline 2015 & urban municipalities & 0.06 & 0.09 \\
& urban-rural municipalities & 1.82 & 3.56 \\
& rural municipalities & 2.60 & 6.01 \\
\hline \multirow{2}{2016}{ urban municipalities } & 0.05 & 0.08 \\
& urban-rural municipalities & 1.48 & 3.25 \\
& rural municipalities & 2.15 & 5.68 \\
\hline \multirow{2}{*}{017} & urban municipalities & 0.04 & 0.07 \\
& urban-rural municipalities & 1.33 & 2.98 \\
& rural municipalities & 1.92 & 5.23 \\
\hline \multirow{2}{*}{018} & urban municipalities & 0.04 & 0.07 \\
& urban-rural municipalities & 1.22 & 2.74 \\
& rural municipalities & 1.76 & 4.74 \\
\hline \multirow{2}{*}{019} & urban municipalities & 0.04 & 0.06 \\
& urban-rural municipalities & 1.14 & 2.58 \\
& rural municipalities & 1.63 & 4.32 \\
\hline
\end{tabular}

Source: Own preparation based on Statistics Poland (2020a). 
Table 4.

Reductions resulting from agricultural tax in municipalities* in 2015-2019 (in thousands PLN and in \%**)

\begin{tabular}{|c|c|c|c|c|c|c|c|c|c|c|}
\hline \multirow[b]{2}{*}{ Specification } & \multicolumn{2}{|c|}{2015} & \multicolumn{2}{|c|}{2016} & \multicolumn{2}{|c|}{2017} & \multicolumn{2}{|c|}{2018} & \multicolumn{2}{|c|}{2019} \\
\hline & $\begin{array}{l}\text { thous. } \\
\text { PLN }\end{array}$ & $\%$ & $\begin{array}{l}\text { thous. } \\
\text { PLN }\end{array}$ & $\%$ & $\begin{array}{l}\text { thous. } \\
\text { PLN }\end{array}$ & $\%$ & $\begin{array}{l}\text { thous. } \\
\text { PLN }\end{array}$ & $\%$ & $\begin{array}{l}\text { thous. } \\
\text { PLN }\end{array}$ & $\%$ \\
\hline \multicolumn{11}{|c|}{ Urban municipalities } \\
\hline lowering upper tax rates & 3.499 & 6.9 & 2.156 & 4.8 & 1.989 & 4.5 & 1.867 & 4.2 & 764 & 1.7 \\
\hline reliefs and exemptions & 35 & 0.1 & 25 & 0.1 & 22 & 0.1 & 22 & 0.1 & 234 & 0.1 \\
\hline tax arrears write-off & 142 & 0.3 & 149 & 0.3 & 75 & 0.2 & 135 & 0.3 & 106 & 0.2 \\
\hline $\begin{array}{l}\text { payment by instalments, } \\
\text { deferring payment date }\end{array}$ & 187 & 0.4 & 249 & 0.6 & 580 & 1.3 & 308 & 0.7 & 59 & 0.1 \\
\hline \multicolumn{11}{|c|}{ Urban-rural municipalities } \\
\hline lowering upper tax rates & 81.253 & 15.0 & 36.073 & 7.0 & 31.539 & 6.2 & 29.128 & 5.8 & 37.008 & 6.9 \\
\hline reliefs and exemptions & 1.180 & 0.2 & 196 & 0.0 & 202 & 0.0 & 282 & 0.1 & 786 & 0.1 \\
\hline tax arrears write-off & 3.076 & 0.6 & 2.077 & 0.4 & 1.894 & 0.4 & 3.544 & 0.7 & 2.674 & 0.5 \\
\hline $\begin{array}{l}\text { payment by instalments, } \\
\text { deferring payment date }\end{array}$ & 1.229 & 0.2 & 1.203 & 0.2 & 888 & 0.2 & 721 & 0.1 & 975 & 0.2 \\
\hline \multicolumn{11}{|c|}{ Rural municipalities } \\
\hline lowering upper tax rates & 206.664 & 20.6 & 99.803 & 10.5 & 82.674 & 8.8 & 80.168 & 8.6 & 91.770 & 9.6 \\
\hline reliefs and exemptions & 2.764 & 0.3 & 1.114 & 0.1 & 1.123 & 0.1 & 894 & 0.1 & 1.028 & 0.1 \\
\hline tax arrears write-off & 7.774 & 0.8 & 6.701 & 0.7 & 4.848 & 0.5 & .096 & 0.6 & 4.752 & 0.5 \\
\hline $\begin{array}{l}\text { payment by instalments, } \\
\text { deferring payment date }\end{array}$ & 2.314 & 0.2 & 1.334 & 0.1 & 1.271 & 0.1 & 1.124 & 0.1 & 1.026 & 0.1 \\
\hline
\end{tabular}

Notes:

* urban municipalities also cover cities with county rights.

** in relation to the income from agricultural tax.

Source: Own preparation based on Ministry of Finance (2015-2019a; 2015-2019b). 


\section{Chart 1.}

The dynamics of revenues from agricultural tax in municipalities in 2015-2019 (in \%) 120

100

80

60

40

20

0

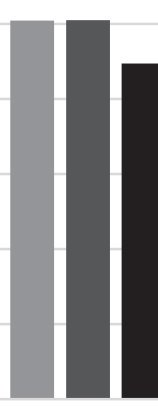

urban municipalities

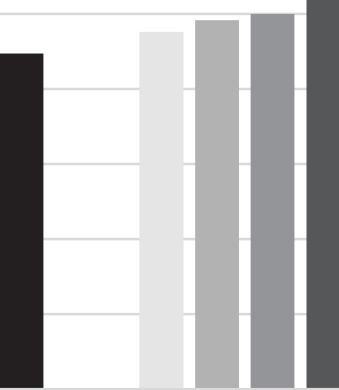

urban-rural municipalities

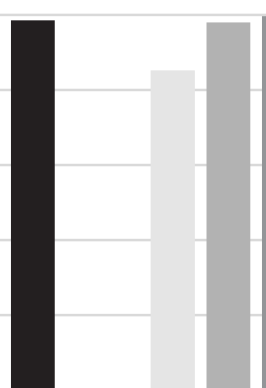

rural municipalities

$$
\begin{aligned}
& \text { 2016/2015 } \\
& \text {-2017/2016 }
\end{aligned}
$$

Source: Own preparation based on Statistics Poland (2020a). 
